\title{
PELATIHAN PENDAMPINGAN PENGEMBANGAN KEPROFESIAN BERKELANJUTAN GURU SMP PLUS AL- QODIRI JEMBER MELALUI PELATIHAN PENULISAN KARYA TULIS ILMIAH
}

\author{
Muhamad Ansori \\ IAI Al-Qodiri Jember \\ muhamadansori87@gmail.com
}

\begin{abstract}
Based on the results of interviews conducted with teachers of SMP Plus Al-Qodiri Jember, it was found that the teachers were still having difficulty in promotion. This difficulty is because the teacher does not have the skills in writing scientific papers, as well as the habit of teachers who never do research. For this reason, it is necessary to make efforts to provide skills to teachers to carry out research, write scientific papers and publish them. One form of simple research that can be easily carried out by teachers is to carry out Classroom Action Research (CAR). In practice, the teacher looks very enthusiastic in participating in the entire series of service activities carried out by this service team, this is because it can be a source of knowledge and hone the teacher's ability to make scientific papers. From the results of observations, it is found that the teachers already have the knowledge and ability to make scientific papers that come from the implementation of Classroom Action Research (CAR).
\end{abstract}

Kata Kunci: Karya Tulis Ilmiah, Pengalaman Terbaik.

Vol. 3 No. 1, A pri 12021 


\section{Pendahuluan}

Pelaksanaan program pengembangan keprofesian berkelanjutan ini diharapkan dapat meningkatkan kompetensi pedagogik, profesional, sosial dan kepribadian untuk memenuhi kebutuhan dan tuntutan masa depan yang berkaitan dengan profesinya sebagai guru. Kegiatan pengembangan keprofesian berkelanjutan dikembangkan atas dasar profil kinerja guru sebagai perwujudan hasil penilaian kinerja guru dan didukung dengan hasil evaluasi diri.

Apabila hasil penilaian kinerja guru masih berada di bawah standar kompetensi yang dipersyaratkan dalam penilaian kinerja guru, maka guru diwajibkan untuk mengikuti program pengembangan keprofesian berkelanjutan yang diorientasikan sebagai pembinaan dalam pencapaian standar kompetensi guru.Sementara itu, guru yang hasil penilaian kinerjanya telah mencapai standar kompetensi yang dipersyaratkan dalam penilaian kinerja guru, kegiatan pengembangan keprofesian berkelanjutan diarahkan kepada pengembangan kompetensi untuk memenuhi layanan pembelajaran berkualitas dan peningkatan karir guru. Sesuai dengan amanat Peraturan Menteri Negara Pemberdayaan Aparatur Negara dan Reformasi Birokrasi Vol. 3 No. 1, A pril 2021 Muhamad Ansori| 140 Zurnal Pengabdian Masyarakat 
Nomor 16 Tahun 2009 tentang Jabatan Fungsional Guru dan Angka Kreditnya, pengembangan keprofesian berkelanjutan merupakan salah satu unsur utama yang diberikan angka kredit untuk kenaikan pangkat/jabatan fungsional guru.

Pelaksanaan kegiatan pengembangan keprofesian berkelanjutan diharapkan dapat menciptakan guru profesional, bukan hanya sekedar memiliki ilmu pengetahuan yang luas, tetapi juga memiliki kepribadian yang matang.Dengan demikian, guru mampu menumbuhkembangkan minat dan bakat peserta didik sesuai dengan bidangnya dalam menguasai ilmu pengetahuan, teknologi, dan seni. Sehingga guru sebagai pembelajar abad 21 mampu mengikuti perkembangan ilmu dalam bidangnya dan dapat memberikan bekal pengetahuan, keterampilan dan sikap yang sesuai dengan standar kompetensi yang harus dimiliki siswa.

Berdasarkan Peraturan Menteri Negara Pendayagunaan Aparatur Negara dan Reformasi Birokrasi Nomor 16 tahun 2009, menyatakan bahwa pengembangkan keprofesian berkelanjutan terdiri dari :

1. Pengembangan diri

2. Publikasi ilmiah.

3. Karya inovatif. 
Pengembangan keprofesian berkelanjutan ini wajib dilakukan oleh guru sebagai bagian yang tak terpisahkan dari penilain kinerja yang dilakukan pada setiap akhir tahun pelajaran. Salah satu unsur PKB yang paling memberikan keuntungan kepada guru karena nilai kreditnya yang cukup besar adalah publikasi ilmiah dalam bentuk pelaksanaan Penelitian Tindakan Kelas (PTK).

Kata PTK digunakan untuk mendeskripsikan/ menguraikan "pengalaman terbaik" mengenai keberhasilan seseorang atau kelompok dalam memecahkan masalah ketika melaksanakan tugas untuk guru terutama adalah pembelajaran disekolahnya. PTK guru dicapai dengan sukses dan lebih cepat jika dilakukan dengan tahapan sistematis melalui pendekatan ilmiah yang langkah- langkahnya dilandasi suatu teori yang relevan dengan masalah pembelajaran.

Berdasarkan data dari Dinas Pendidikan Kabupaten Sarolangun (data statistik tahun 2012) menyebutkan bahwa tidak ada satupun guru yang mampu mencapai pangkat IV /B, kebanyakan mereka tertahan pada golongan IV/ A. Berdasarkan data dan hasil wawancara awal penulis dengan sebagian guru yang belum mampu memasuki gol IV/ A menyebutkan bahwa mereka tidak bisa naik pangkat ke golongan IV/B dikarenakan: (1) Kemampuan guru dalam melaksanakan publikasi 
ilmiah terutama dalam membuat karya tulis berdasarkan pengalaman terbaiknya dalam melaksanakan pembelajaran; (2) Pemahaman guru tentang penulisan karya tulis berdasarkan pengalaman terbaiknya dalam melaksanakan kegiatan akademik di sekolah masih lemah; (3) Kebiasaan guru menulis dan meneliti untuk publikasi ilmiah sangat kurang sekali hal ini akan menjadi penggalang utama dalam menaikan jenjang kepangkatan.

Dalam kegiatan pengabdian masyarakat ini mengadakan mitra dengan Seluruh Lembaga dibawah naungan Yayasan Al-Qodiri Jember dengan fokus utamnya yaitu pada guru SMP Plus Al-Qodiri Jember. Penetapan sekolah ini didasarkan beberapa pertimbangan antara lain: (1) Jumlah guru yang mengajar di SD tersebut cukup banyak yang tertahan di golongan III/c; (2) SMP Plus Al-Qodiri Jember ini dijadikan sekolah formal dalam pesantren Al-Qodiri yang nanti akan menjadi contoh bagi bagi lembaga-lembaga lainnya dibawah naungan Yayasan Al-Qodiri Jember; dan (3) Guru -guru di SMP Plus Al-Qodiri tersebut belum - tidak memahami tentang pengembangan kepofesional berkelanjutan dalam bentuk publikasi ilmiah berupa karya tulis berdasarkan pengalaman terbaiknya dan perlu mendapatkan pelatihan. Dari uraian permasalahan di atas, tujuan dilaksanakan kegiatan 
penulisan karya tulis ilmiah berdasarkan PTK guru di SMP Plus AlQodiri Jember ini yaitu: (1) Memberikan pengetahuan dan pemahaman penulisan karya tulis ilmiah berdasarkan PTK guru; (2) Meningkatkan kualitas diri guru yang memiliki kemampuan dalam melakukan penulisan karya tulis ilmiah berdasarkan PTK guru; dan Meningkatkan kualitas pembelajaran pada SMP Plus Al-Qodiri Jember melalui peningkatan kemampuan penulisan karya tulis ilmiah berdasarkan PTK guru.

\section{Kajian Pustaka}

Kegiatan publikasi ilmiah guru semakin diperkuat dengan hadirnya Permenpan dan RB No. 16 tentang Jabatan Fungsional Guru dan Angka Kreditnya. Semula kewajiban publikasi ilmiah hanya dikenakan kepada guru yang akan naik pangkat dari Golongan IV.a ke atas. Namun berdasarkan Permenpan dan RB ini, kegiatan publikasi ilmiah guru harus dilakukan oleh guru yang akan naik ke golongan III.c.

Di Indonesia, kegiatan publikasi ilmiah di kalangan guru tampaknya mulai populer pada pertengahan tahun 90-an, seiring dengan dikukuhkannya guru sebagai jabatan fungsional (Permen PANRB Nomor 16 tahun 2009) . Jika ditelaah lebih dalam, Isi Keputusan Menteri ini sebenarnya telah memberikan pesan tidak 
langsung kepada kita bahwa pada dasarnya guru adalah seorang ilmuwan. Hal ini sejalan dengan pemikiran Hamalik (2003) bahwa salah satu peran guru adalah sebagai ilmuwan, yang berkewajiban tidak hanya menyampaikan pengetahuan yang dimiliki kepada muridnya, akan tetapi juga berkewajiban mengembangkan pengetahuan itu dan terus menerus memupuk pengetahuan yang dimilikinya. Dengan kata lain, guru berkewajiban untuk membangun tradisi dan budaya ilmiah, salah satunya dalam bentuk Publikasi Ilmiah.

Merujuk pada Permenpan dan RB No. 16 tentang Jabatan Fungsional Guru dan Angka Kreditnya, berikut ini disajikan bentukbentuk kegiatan publikasi ilmiah yang dapat dilakukan guru dalam rangka pengembangan keprofesian berkelanjutan, yaitu: (1) Presentasi pada forum ilmiah; (2) Melaksanakan publikasi Ilmiah hasil penelitian atau gagasan ilmu pada bidang pendidikan formal; dan Melaksanakan publikasi buku teks pelajaran, buku pengayaan, dan pedoman guru.

PTK memiliki ciri-ciri atau indikator sebagai berikut : (1) mengembangkan cara baru dan inovatif dalam pengembangan serta memecahkan masalah dalam pendidikan khususnya pembelajaran; (2) membawa sebuah perubahan/perbedaan sehingga sering dikatakan 
hasilnya luar biasa (outstanding result); (3) mampu mengatasi persoalan tertentu secara berkelanjutan (keberhasilan lestari) atau dampak dan manfaatnya berkelanjutan; (4) mampu menjadi model, memberi inspirasi dalam membuat kebijakan (pejabat), dan inspiratif guru lainnya, termasuk murid; dan (5) Cara dan metoda yang dilakukan dan atau yang digunakan bersifat ekonomis dan efisien.

Biasanya hasil penulisan PTK tersebut akan diperlombakan di tingkat daerah dan nasional, sehingga tulisan tentang pengalaman tersebut bisa diketahui oleh para pendidik lainnya lainnya minimal oleh peserta lomba. PTK atau pengalaman terbaik dalam pembelajaran, memerlukan ilmu pengetahuan dan seni untuk dipakai sebagai landasannya. Setiap data dan atau catatan (rekam jejak) kemajuan keberhasilan selama mengatasi masalah pembelajaran terdokumentasikan secara baik sehingga bermanfaat untuk merumuskan Standard Operating Procedure (SOP) yang apabila ditiru (replikasi) oleh guru yang lainya memperoleh hasil yang sama.

Salah satu tahapan penting agar pembelajaran bisa menjadi salah satu best practice, yaitu evaluasi diri. Evaluasi terhadap cara atau strategi yang telah dilaksanakan, hasil (output dan outcome), dan apabila memungkinkan mengevaluasi dampaknya. Dari hasil evaluasi 
tersebut, guru mampu menemukan kesenjangan antara bagaimana pembelajaran yang telah dilakukan dengan teori pembelajaran, termasuk kesenjangan keberhasilannya sehingga muncul ide dan motivasi untuk menutup kesenjangan tersebut dalam rangka memecahkan masalah yang dihadapi.

Dengan demikian PTK guru, merupakan sebuah publikasi ilmiah yang memaparkan hal ihwal pengalaman terbaik yang telah dilakukan selama melaksanakan tugas tugasnya dalam pembelajaran termasuk mengatasi masalah jika ada, dengan ciri-ciri: (1) inovatif, (2) outstanding result, (3) keberhasilan lestari, (4) mampu menjadi model, (5) memberi inspirasi, dan (6) ekonomis serta efisien.

\section{Metode Pelaksanaan Pengabdian}

Kerangka pemecahan masalah dari pelaksanaan penulisan karya tulis ilmiah berdasarkan PTK guru di SMP Plus Al-Qodiri Jember dapat dilihat pada gambar 1 berikut: 


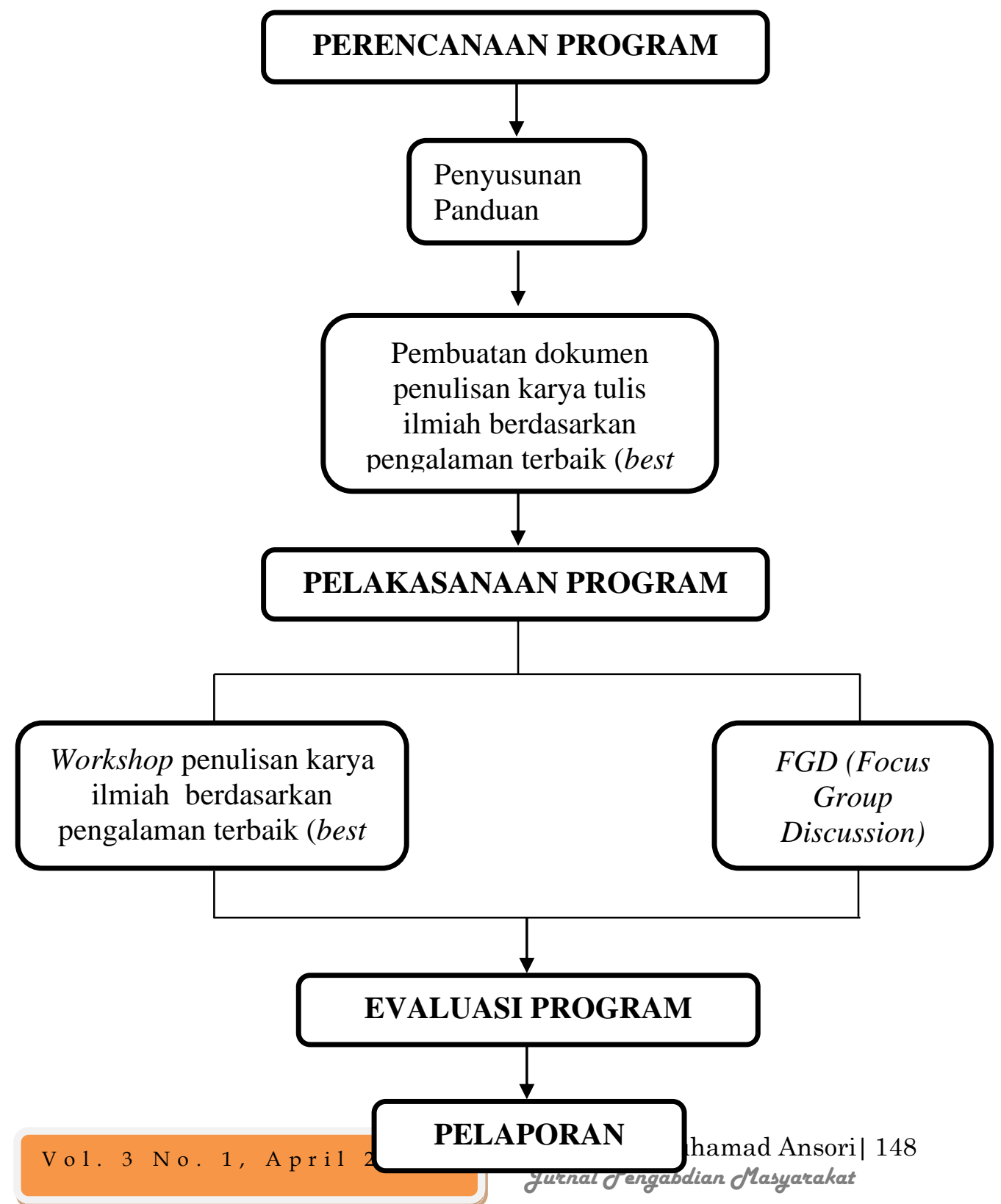


Gambar 1. Kerangka Pemecahan Masalah

Pengabdian oleh tim kerja ini dilaksanakan pada SMP Plus AlQodiri Jember, dengan bentuk kegiatan berupa sosialisasi, workshop dan tugas mandiri. Kegiatan ini dilaksanakan selama 3 bulan. Adapun tahapan dalam kegiatan ini adalah :

\section{Tahap Pertama : Survai Pendahuluan}

Dalam kegiatan survai ini tim bertemu dengan kepala sekolah untuk membicarakan tentang kondisi awal sekolah terutama berkaitan guru dalam membuat karya tulis ilmiah, seperti PTK atau karya ilmiah yang lainnya. Dari hasil pembicaraan dan pengamatan ternyata sebagaian besar guru belum sepenuhnya memahami pembuatan pengalaman terbaik (best practices). Menurut kepala sekolah kelemahan guru dalam membuat PTK dikarenakan belum sepenuhnya guru memahami pembuanatan pengalaman terbaik (best practices). Kurangnya sosialisasi dan bimbingan dari pengawas menjadi salah satu kendala guru dalam membuat PTK yang baik dan benar.

\section{Tahap kedua}

Tim pengabdian bertemu dengan guru, melakukan wawancara 
untuk mengetahui tentang penulisan karya ilmiah berupa PTK yang sudah pernah dilakukan oleh guru. Dalam kegiatan ini tim pengabdian melakukan sosialisasi atau pemberian materi tentang seputar penulisan PTK dan manfaatnya pembuatan PTK dalam menyosong meningkatkan kualifikasi profesionalisme guru. Dalam sosialisasi ini dihadiri semua guru di SMP Plus Al-Qodiri Jember dan pengawas pembina sekolah tersebut.

\section{Tahap ketiga}

Tim pengabdian melakukan kegiatan workshop pembuatan pengalaman terbaik (best practices), dimana setiap guru diberikan latihan dalam menyusun dan mengembangkan proposal PTK yang baik dan benar sesuai dengan bidang studi masing masing. Pada akhir kegiatan masing masing guru melakukan presentasi proposal pengalaman terbaik (best practices), hasil kerja mereka sesuai dengan materi yang sudah diberikan oleh tim pengabdian. Kegiatan ini dilakukan selama 4 hari dari tanggal 19-22 Oktober 2020.

\section{Tahap keempat}

Peserta diberi tugas untuk melaksanakan PTK sesuai dengan proposal yang sudah disusun dengan perbaikan. Sebelum 
melaksanakan, guru membuat instrumen pengumpulan data sesuai dengan tujuan PTK yang disusun. Tim memberikan batas waktu 1 minggu untuk membuat instrument pengumpulan data dan mengumpulkannya kepada tim pengabdian untuk divalidasi.

\section{Tahap kelima}

Pada tahap ini peserta diminta untuk melakukan PTK sesuai dengan jadwal kegiatan yang sudah ditentukan. Selanjutnya guru diberikan waktu selama tiga minggu untuk tahap ini sekaligus peserta disuruh untuk membuat laporan hasil PTK yang sudah dilakukan. Peserta diharapkan untuk terus berkomunikasi dengan tim pengabdian untuk mengatasi kesulitan-kesulitan yang mungkin dihadapi oleh peserta selama melakukan tahap ini.

\section{Tahap keenam}

Peserta melakukan presentasi/penyajian laporan PTK yang sudah dilakukan dengan dibimbing oleh tim pengabdian. Selanjutnya, dilakukan refleksi sesama peserta untuk perbaikan kegiatan selanjutnya. Kegiatan ini dilakukan selama satu hari penuh.

Selama proses pengabdian ini peserta menunjukkan sikap keantusiasan mereka dalam memperhatikan pembelajaran yang 
diberikan peneliti. Mereka lebih aktif berpartisipasi dalam kegiatan pembelajaran, misalnya aktif dalam merespon pertanyaan yang diajukan guru serta aktif dalam berdiskusi. Peserta juga terlihat serius dan bertanggung jawab terhadap tugas yang diberikan, suasana diskusi kelompopok juga terlihat sangat antusias

Pengabdian masyarakat yang dilakukan dapat dikatakan berlangsung dengan lancar dan penuh semangat, semua peserta semangat dalam mengikuti kegiatan ini, hal ini dikarenakan selama ini belum pernah mendapatkan bimbingan dan pendampingan dalam membuat dan mengembangan PTK. Pada prinsipnya selama kegiatan berlangsung terjadi interaksi yang sangat positif antara peserta pelatihan dengan nara sumber maupun antar sesama peserta.

\section{Hasil dan Diskusi}

1. Terciptanya suasana dan kondisi ilmiah dalam proses pembelajaran dan upaya pemecahan masalah dalam kaitannya dengan peningkatan kualitas profesionalisme guru.

2. Guru memahami tentang hakikat PTK.

3. Guru mengetahui manfaat dan tujuan PTK untuk meningkatkan kualitas profesionalisme guru. 
4. Timbulnya motivasi guru dalam membuat PTK walaupun masih sederhana.

Selama kegitan berlangung dan selesainya kegiatan semua peserta merasakan manfaat yang besar dari hasil pelatihan, dimana mereka sangat menyadari betapa pentingnya pelaksanaan PTK bagi peningkatan kualitas pendidik terutama dalam peningkatan kualitas pembelajaran yang berkorelasi dengan keberhasilan peserta didik. Dengan pembuatan PTK guru akan lebih terarah dalam kegiatan pembelajaran.

Dengan berakhirnya kegiatan. Guru sangat mengharapkan agar kegiatan serupa bisa dilaksanakan disekolah mereka maupun sekolah lain untuk peningkatan profesionalisme guru. Kepala sekolah juga memohon agar sekolahnya dijadikan sasaran pengabdian maupun penelitian dari IAI Al-Qodiri Jember khususnya dari Program Studi Pendidikan Agama Islam. Melalui Pengawas permohonan juga disampaikan agar seluruh Lembaga dibawah naungan Yayasan AlQodiri Jember ini dijadikan untuk kegiatan pengabdian dosen dalam upaya membantu sekolah meningkatkan kualitas pembelajaran disekolah secara terus menerus. 


\section{Kesimpulan}

Berdasarkan kegiatan pengabdian masyarakat yang dikalaksanakan di SMP Plus Al-Qodiri Jember dapat disimpulkan sebagai berikut :

1. Guru sangat antusias dalam mengikuti kegiatan pembuatan PTK hal ini dibuktikan dengan semangat mengikuti kegiatan dari awal dan akhir dengan disertai berjalannya diskusi dan tanya jawab yang serius.

2. Guru belum terbiasa membuat PTK dengan baik dan benar sesuai dengan prosedur ilmiah.

3. Perlu adanya bimbingan secara kontinyu dalam penyusunan PTK .

\section{Saran}

1. Pengurus Yayasan Al-Qodiri Jember khususnya Kepala dan Pengelola SMP Plus Al-Qodiri Jember, harus lebih memperhatikan pengembangan keprofesian guru-gurunya hal ini penting untuk kelanjutan karir bagi guru.

2. Perlunya diadakan Workshop ataupun pelatihan penulisan karya ilmiah secara terus menerus dengan Perguruan Tinggi sekitar 
termasuk dengan dinas Pendidikan terkait untuk menciptakan guruguru yang professional dengan karir yang lebih cerah kedepannya.

\section{Daftar Pustaka}

Disdik Gresik. Pedoman Penulisan PTK KKG/ MGMP. Gresik: Dinas Pendidikan. 2015.

Hamalik, O. Guru Profesional. Bandung: Rosdakarya. 2003.

Kemdikbud. Pedoman Lomba Penulisan PTK Pengawas Sekolah Dalam

Pelaksanaan Tugas Pengawasan. Jakarta: Direktorat Pembinaan

Pendidik Dan Tenaga Kependidikan Pendidikan Menengah,

Direktorat Jenderal Pendidikan Menengah. 2013.

Permenpan dan RB No. 16 tentang Jabatan Fungsional Guru dan Angka Kreditnya

Undang-Undang Nomor 20 Tahun 2003 tentang Sistem Pendidikan Nasional,

Undang Undang No 14 Tahun 2005 tentang Guru dan Dosen

Peraturan Pemerintah Republik Indonesia Nomor 32 Tahun 2013 Tentang Perubahan Atas Peraturan Pemerintah Nomor 19 Tahun 2005 Tentang Standar Nasional Pendidikan 


\section{JURNAL}

\section{As-Sidanah}

Vol. 03 No. 1, April 2021 